\title{
The effect of synthesis method and post-synthesis treatment on the formation of neutral Mn(II) complex into anionic zeolite structure and investigation of its catalytic activity in the epoxidation of alkenes
}

\author{
Maryam Moosavifar • Abdolali Alemi · \\ Mohammad Reza Marefat • Nasrin Nouruzi • \\ Hossein Mahmoodi
}

Received: 16 June 2013/ Accepted: 7 February 2014/Published online: 3 April 2014

(c) The Author(s) 2014. This article is published with open access at Springerlink.com

\begin{abstract}
In this study, we improved the catalytic performance of manganese porphyrin encapsulated HY zeolite for alkene epoxidation reaction. For this purpose, Manganese tetra pyridyl porphyrin encapsulated into modified dealuminated Y zeolite (MnTPP-MDAZY) was synthesized using zeolite template synthesis method. This heterogenized catalyst was characterized by FT-IR, UV-Vis, $\mathrm{XRD}$ and atomic absorption spectra (AAS) technique. Catalyst loading was $0.263 \mathrm{mmol} / \mathrm{g}$ support. In this way, high catalyst loading is probably related to the decrease of the size of metalloporphyrin and the post-synthesis treatment. The latter one causes the increase of the diameter of the mesoporous structure as a result of the dealumination of zeolite with EDTA treatment. High catalyst loading efficiently enhances the epoxidation of alkenes.
\end{abstract}

Keywords Manganese porphyrin - Dealuminated zeolite $\mathrm{Y} \cdot$ Zeolite template synthesis - Catalyst loading · Alkene epoxidation

\section{Introduction}

Zeolite-encapsulated metal complexes have attracted special attention as modern catalytic systems and as model compounds for enzyme mimicking [1]. In this case,

M. Moosavifar $(\bowtie) \cdot$ M. R. Marefat · N. Nouruzi .

H. Mahmoodi

Department of Chemistry, Faculty of Science, University of

Maragheh, P.O. Box 55181-83111, Maragheh, Iran

e-mail: m.moosavifar90@gmail.com

A. Alemi

Department of Inorganic Chemistry, University of Tabriz,

51667 Tabriz, Iran metallocomplexes act as an active site enzyme and the zeolite framework represents a rigid protein mantle of enzymes [2-6]. Therefore, they will have many advantages including high thermal and chemical stability that related to the reducing of self-destruction and degredation of metallocomplexes. Thus, the recovery and reusability of these systems may be because of heterogeneity of these systems [7-11]. In addition, these catalytic systems indicate the shape and size selectivity due to the molecular size channels and pores in three-dimensional network of welldefined crystalline structures [7, 12].

Typically, zeolites are considered as crystalline microporous aluminosilicate materials with periodic arrangements of nanocages and nanochannels. These compounds have industrial applications including adsorbents, ion exchangers and catalysts which are related to high surface area, high stability, exchangeable cations and uniform cavities. Zeolites have been thus categorized according to their porous dimensions as small, medium and large pore sizes $[10,13,14]$. In other words, in these porous materials, some of the macromolecules cannot incorporate inside the pores of zeolite owing to their large size. To facilitate the interaction between the support and macromolecules, the supports with large pores are likely suitable to incorporate supramolecules such as porphyrins, phthalocyanines, Schiff bases and polyoxometallates. Therefore, several interesting strategies have been performed in this field including the usage of mesoporous material, for instance, MCM-41 and SAPO-21 or post-synthesis treatment. In the post-synthesis treatment, secondary mesoporous structure is formed using the dealumination of zeolite [7, 10, 15-17]. It leads to high $\mathrm{Si} / \mathrm{Al}$ ratio and consequently the replacement of large macromolecules such as porphyrin in the supercage of zeolite becomes possible [18]. All of Mn porphyrins encapsulated into zeolite which have been 


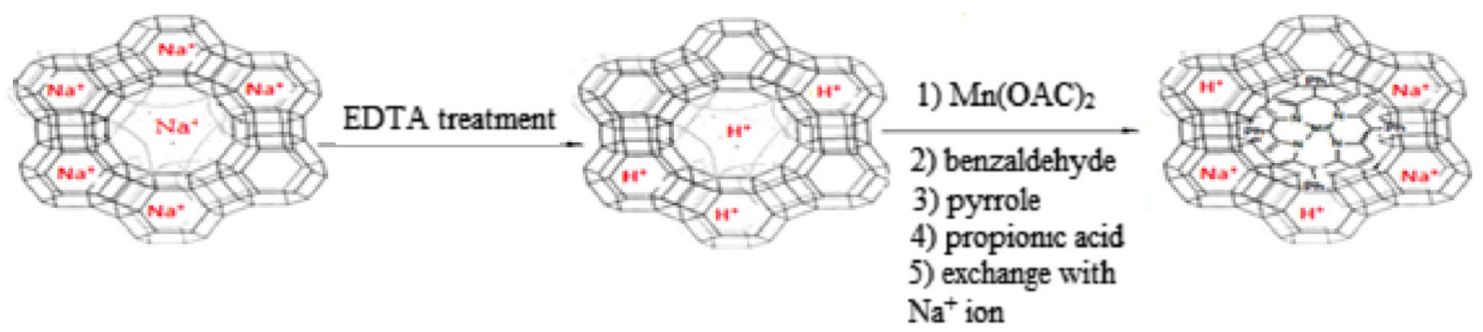

Scheme 1 Synthesis of manganese (II) tetra pyridyl porphyrin into modified dealuminated Y zeolite

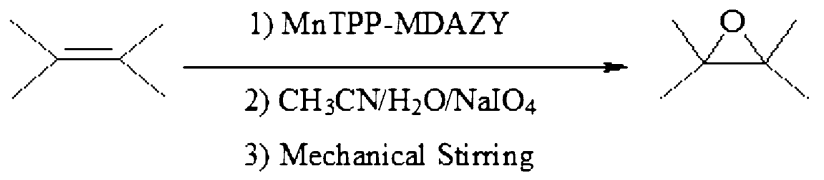

Scheme 2 Oxidation of alkenes with $\mathrm{NaIO}_{4}$ catalyzed by MnTPPMDAZY

studied until now have oxidative states that equal 3. They are scarcely reported in the literature for the oxidative state of $\mathrm{Mn}(\mathrm{II})$ porphyrin encapsulated into dealuminated $\mathrm{Y}$ zeolite. This can related to the anionic structure of zeolite which mostly allows the formation of cationic species more than neutral and anionic species into nanocage of zeolite [19]. However, upon the dealumination of zeolite with EDTA treatment, $\mathrm{Si} / \mathrm{Al}$ ratio increases because of the replacement of $\mathrm{AlO}_{4}{ }^{-}$by $\mathrm{SiO}_{4}$. Consequently, the negative charge of zeolite is reduced; therefore, it probably facilitates the inclusion of neutral complexes into zeolite cages.

In this study, we attempted to continue and modify our previous work on the encapsulation of metalloporphyrin into supercage of zeolite using built-bottle-around-ship method [20] and post-synthesis treatment. Here, we wish to report the preparation and physicochemical characterization of manganese (II) tetra pyridyl porphyrin into modified dealuminated Y zeolite (MnTPP-MDAZY) through zeolite template synthesis method for the first time (Scheme 1). Then, the catalytic activity of this system was investigated in the epoxidation of alkenes with $\mathrm{NaIO}_{4}$ under mechanical stirring (Scheme 2). Based on the usage of modified dealuminated $\mathrm{Y}$ zeolite with EDTA treatment, the catalyst loading increased and therefore, effective epoxidation reaction occurred.

\section{Experimental}

All solvents and reagents were of commercial grade and attained from Merck, Fluka and Sigma-Aldrich. AAS were recorded on an Analytikjena nov AA 400 Spectrophotometer using a flame approach. Gas chromatography (GC) experiments were carried out with a Shimadzu GC-2010 instrument using a 2-m column peaked with silicon DC200 or Carbowax $20 \mathrm{~m}$ using $n$-Decane as internal standard. The electronic spectra of free complex and encapsulated complex in the UV-Vis region were recorded in methanol solution for MnTPP and in sulfuric acid for MnTPP-MDAZY to digest zeolite structure using UV-1700 PharmaSpec Shimadzu. FT-IR spectra were obtained in the range $400-4,000 \mathrm{~cm}^{-1}$ with a Tehsor 27-BRUKER instrument. Powder X-ray diffraction of the free complex and encapsulated complex (samples) was performed with $\mathrm{Cu} \mathrm{K}_{\alpha}$ radiation. $\mathrm{NaY}$ zeolite was purchased from SigmaAldrich. Y zeolite was dealuminated using (ethylenediaminetetraacetic) acid $\mathrm{H}_{4}$ EDTA by chemical operation according to the reported procedure. In this case, the rate of $\mathrm{H}_{4}$ EDTA addition, amount of $\mathrm{H}_{4}$ EDTA and reaction temperature should be controlled to minimize the amorphization of zeolite [21]. The dealuminated sample was washed with hot distilled water dried and finally was used in the synthesis of manganese porphyrin inside nanocage of zeolite [22]. In a typical procedure, a solution of $3 \mathrm{~g}$ $\mathrm{Mn}(\mathrm{OAC})_{2}, 4 \mathrm{H}_{2} \mathrm{O}$ was ion-exchanged with $6 \mathrm{~g}$ of modified dealuminated zeolite (MDAZY) in $100 \mathrm{ml}$ deionized water and then was stirred at $50{ }^{\circ} \mathrm{C}$ for $24 \mathrm{~h}$. The slurry was filtered off and pinkish white solid product was washed by hot distilled water. To prepare manganese tetra pyridyl porphyrin in the supercages of zeolite, $900 \mu$ l (equal $0.873 \mathrm{~g}$ ) pyrrol, $1,320 \mu \mathrm{l}$ (equal $1.386 \mathrm{~g}$ ) fresh distilled benzaldehyde and $2 \mathrm{~g}$ MDAZY were mixed in $50 \mathrm{ml}$ with propionic acid according to the reported procedure (Scheme 1) [22]. The final mixture was refluxed in oil bath for $18 \mathrm{~h}$ at $393 \mathrm{~K}$ under nitrogen atmosphere and then filtered off. The crude solid was then purified with soxhlet extractor for removal of metal complexes on the external surface and a brown solid was obtained. To remove the unreacted species of Mn cations in the pores of zeolite, the sample was exchanged with aqueous $0.01 \mathrm{M}$ solution of $\mathrm{NaCl}$ for $24 \mathrm{~h}$ under vigorous stirring. Finally, the catalyst was filtered, washed with distilled water and it was dried at $363 \mathrm{~K}$. To confirm the location of MnTPP into supercage of zeolite, the sample was studied by spectroscopic techniques such as FT-IR, UV-Vis and XRD technique. The catalyst loading was also determined using AAS and the 
progress of reaction was monitored by gas chromatography.

The catalytic activity of this system was investigated in the alkene epoxidation reaction. In a typical procedure, to a mixture of alkene $(0.5 \mathrm{mmol})$, imidazole $(1.4 \mathrm{mmol})$, manganese porphyrin (0.05 mmol of MnTPP-MDAZY) and $\mathrm{CH}_{3} \mathrm{CN}(5 \mathrm{ml})$ was added a solution of $\mathrm{NaIO}_{4}$ (1 mmol) in $\mathrm{H}_{2} \mathrm{O}(2.5 \mathrm{ml})$ and was stirred at room temperature. The progress of reaction was tested by GLC. The reaction mixture was filtered and thoroughly washed with $\mathrm{Et}_{2} \mathrm{O}(20 \mathrm{ml})$. The crude filtrates were purified on a silicagel plate or a silica-gel column and identified by IR and ${ }^{1} \mathrm{H}$ NMR spectral data.

\section{Result and discussion}

\section{Preparation and characterization of MnTPP-MDAZY}

The synthesis of modified dealuminated $\mathrm{Y}$ zeolite-encapsulated Mn(II)-porphyrin, MnTPP-MDAZY was carried out by a zeolite template synthesis method [22]. For this purpose, first we prepared MDAZY using post-synthesis treatment [21]. In this method, unlike to other dealumination processes, not only the further dealumination takes place but also the extra-framework aluminum species are removed from the secondary pores [24]. Thus, $\mathrm{Si} / \mathrm{Al}$ ratio, number and diameter of mesoporous structure increase. Consequently, the probability of the formation of catalyst inside nanocage of zeolite enhances, too [23]. Then, MnTPP was synthesized into supercage of zeolite by template synthesis method [22].

In accordance to the immobilization of metallocomplexes on zeolite surface, the leaching of catalyst occurred from the external surface of zeolite during washing and the color of the zeolite was changed. Meanwhile, in the encapsulation method, upon formation of metalloporphyrin into supercage of zeolite, the color of originally white zeolite has been turned to brown (harsh brown). After purification with soxhlet extraction, the color of obtained material remained unchanged. This proves the incorporation of metallocomplex into zeolite cage not on the external surface.

Figure 1 shows the XRD patterns of the MDAZY and the modified dealuminated $\mathrm{Y}$ zeolites-encapsulated
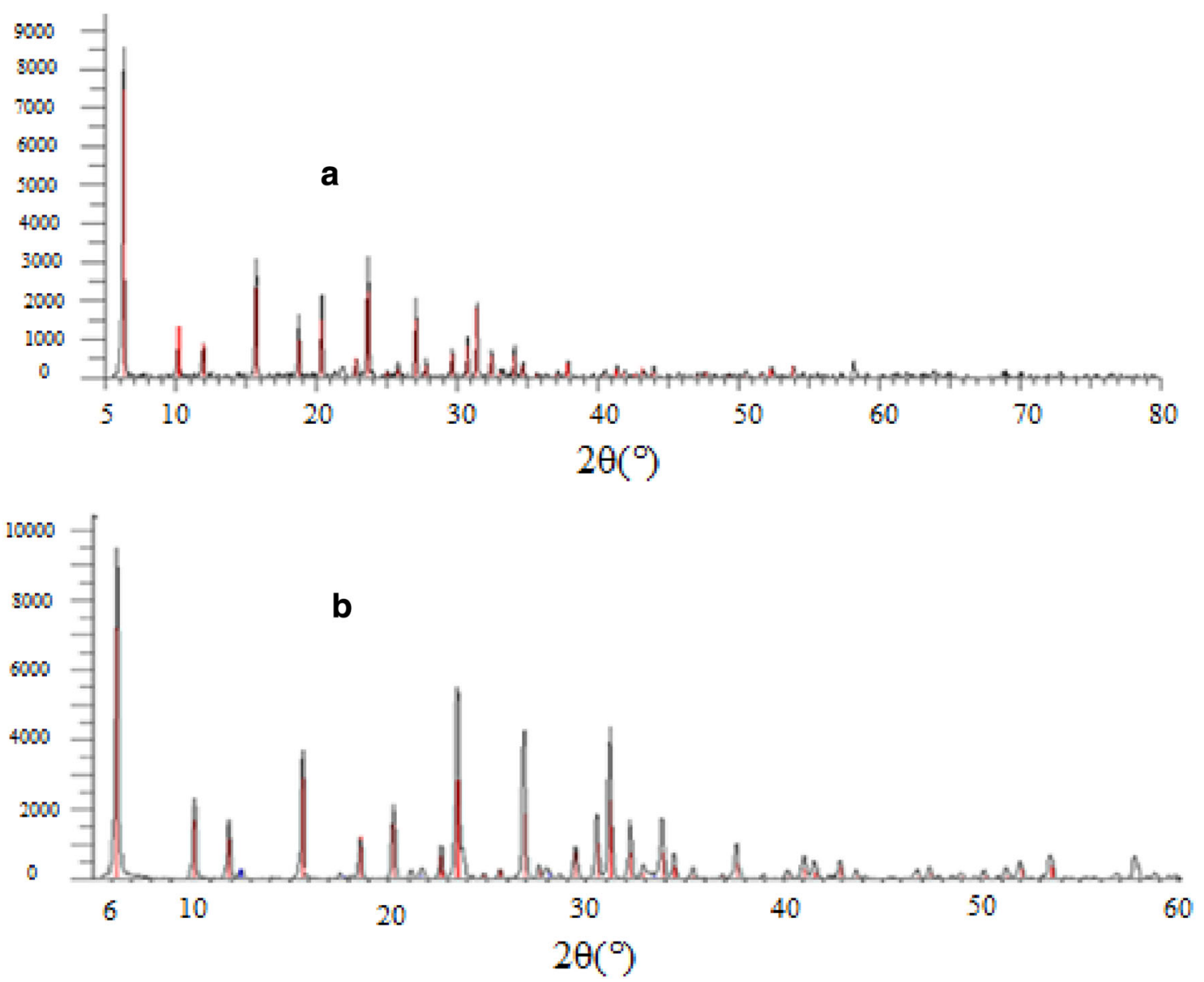

Fig. 1 X-ray diffraction patterns of a MDAZY, b MnTPP-MDAZY 
Table 1 Amount of metalloporphyrin into the MDAZY and UV-Vis absorption bands for MnTPP

\begin{tabular}{llllll}
\hline Entry & Catalyst & $\begin{array}{l}\text { Metalloporphyrin loading } \\
(\text { mmol/g zeolite })\end{array}$ & \multicolumn{3}{l}{ Wavelength $(\mathrm{nm})$} \\
\cline { 5 - 6 } & & & CT-band & Q-band & Soret band \\
\hline 1 & MnTPP & - & 420 & $470(\lambda$ max $)$ & 560 \\
2 & MnTPP-MDAZY & 0.263 & 419 & 471 & 560
\end{tabular}

manganese porphyrin (MDAZY-MnTPP). The second pattern (MDAZY-MnTPP) has crystallinity almost similar to that of the parent MDAZY. Upon the encapsulation of metallocomplex in the supercage of zeolite, the crystallinity of zeolite remains unchanged. This is related to the formation of metallocomplex in the zeolite structures without any disruption which in turn can be attributed to their fine distribution in the lattice of zeolite [25, 26].

Also, UV-Vis spectrum of MnTPP-MDAZY after digestion in concentrated $\mathrm{H}_{2} \mathrm{SO}_{4}$ shows bands relating to metalloporphyrin (Table 1). These bands confirm the incorporation of MnTPP into the supercage of the zeolite. The comparison of UV-Vis spectrum of MnTPP-MDAZY with free MnTPP reveals no shift in the position of $Q$ and soret bands. This means that the location of metallocomplexes into supercage of zeolites without any spatial confinement can be related to the size and the pore diameter of metallocomplexes.

The FT-IR spectra can also provide information about the formation of MnTPP inside the supercage of the zeolite which is shown in the Fig. 2a, b. The strong band in the region of $1,000 \mathrm{~cm}^{-1}$ could be attributed to the asymmetric stretching vibrations of ( $\mathrm{Si} / \mathrm{Al}) \mathrm{O}_{4}$ units (Fig. 2b) [27] where the main bands associated with vibrational transitions of porphyrins can be observed (Fig. 2a). The broadening of peaks or shifts in the position of peaks in the regions of 1,000 and $3,400 \mathrm{~cm}^{-1}$ can be due to dealumination of the zeolite [22]. The band at the 1,639 and $3,439 \mathrm{~cm}^{-1}$ is related to lattice water molecules and surface hydroxylic groups (Fig. 2b). However, the bands observed in the $1,200-1,600 \mathrm{~cm}^{-1}$, where zeolite has no bands, prove the existence of metalloporphyrin in the zeolite nanopores. In addition, bands at 1,150-1,650 and $2,800-3,200 \mathrm{~cm}^{-1}$ are attributed to $\mathrm{C}-\mathrm{C}$ and $\mathrm{C}=\mathrm{N}$ vibrations of the porphyrin ring and $\mathrm{C}-\mathrm{H}$ vibrations for the MnTPP-MDAZY, respectively [28] (Fig. 2a, b).

Furthermore, the amount of manganese porphyrin into supported catalyst was determined by atomic absorption spectroscopy which shows the value of $0.263 \mathrm{mmol} / \mathrm{g}$ support for MnTPP-MDAZY. In comparison with our previous work [20] and others' results [22] which refers to post-synthesis treatment, these results indicate an interesting trend. When the $\mathrm{Si} / \mathrm{Al}$ ratio enhances based on the dealumination of zeolite, the capacity of cations exchange and consequently, the number of occupied sites increases. So, catalyst loading enhances [29].

In general, the change in color and amount of catalyst loading in comparison with our previous work can be attributed to the following factors: (1) the size of the metallocomplex and (2) post-synthesis treatment. The second factor causes the more formation of secondary mesoporous structure, which results to the increase in catalyst loading

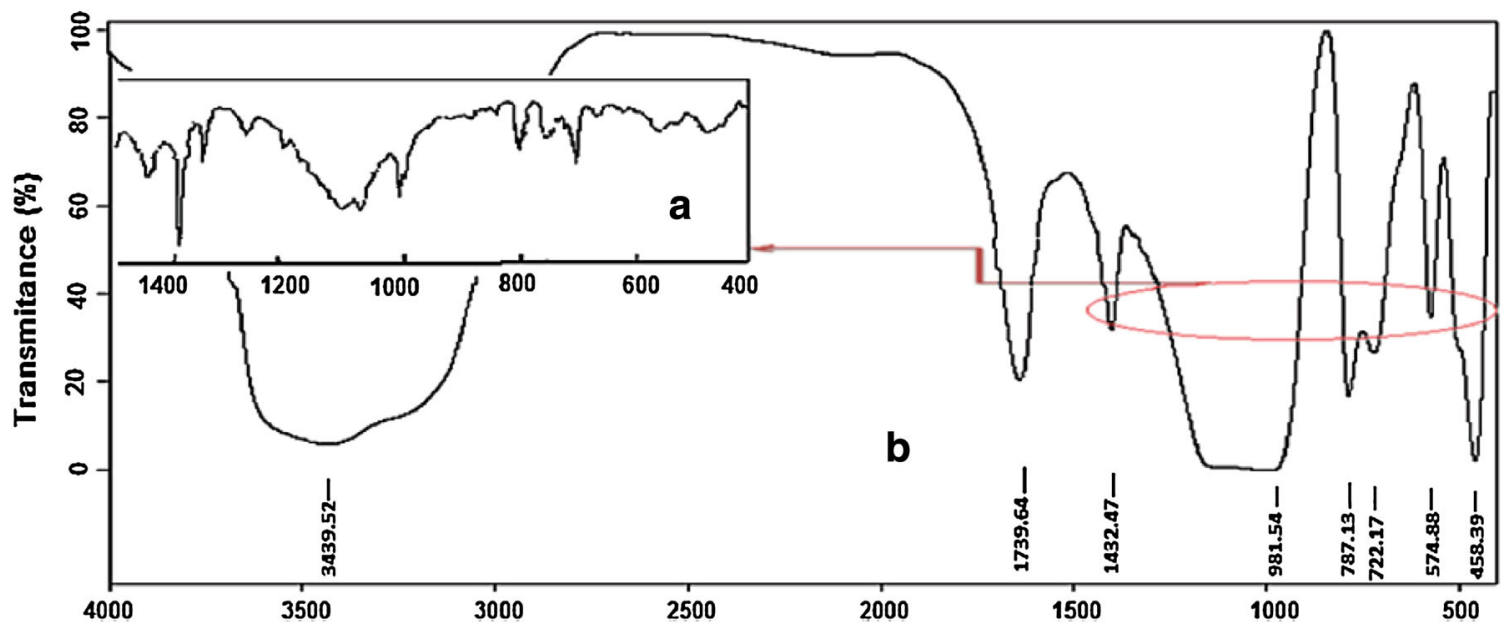

Fig. 2 FT-IR spectra of a MnTPP, b MnTPP-MDAZY 
Table 2 The effect of catalyst amount on the epoxidation of cyclooctene with $\mathrm{NaIO}_{4}$ catalyzed by MnTPP-MDAZY at room temperature

\begin{tabular}{llll}
\hline Entry & Catalyst loading $(\mathrm{mg})$ & Time $(\mathrm{h})$ & Epoxide yield $(\%)^{\mathrm{a}}$ \\
\hline 1 & 100 & 6 & 75 \\
2 & 150 & 5 & 80 \\
3 & 200 & 3.5 & 100 \\
4 & 300 & 3 & 100
\end{tabular}

Cyclooctene $(0.5 \mathrm{mmol}), \mathrm{NaIO}_{4}(1 \mathrm{mmol})$, Catalyst, $\mathrm{CH}_{3} \mathrm{CN} / \mathrm{H}_{2} \mathrm{O}$ $(5 \mathrm{ml} / 2.5 \mathrm{ml})$

${ }^{\mathrm{a}} \mathrm{GC}$ yield

and the color of product to be intense. These results are consistent with atomic absorption spectroscopy data. Accordingly, this factor effects on the reactivity of encapsulated metallocomplexes in the epoxidation of alkenes.

Catalytic alkene epoxidation with $\mathrm{NaIO}_{4}$

in the presence of MnTPP-MDAZY

under mechanical stirring

First, the optimum amount of catalyst in the epoxidation of cyclooctene was investigated. The best results were obtained with $0.2 \mathrm{~g} / \mathrm{g}$ support (eq $0.053 \mathrm{mmol}$ of MnTPP) (Table 2). Epoxidation of alkenes with sodium periodate in the presence of MnTPP-MDAZY under magnetic stirring produces the corresponding epoxides in aqueous acetonitrile at room temperature. The obtained results have been compared with our previous work [20] and are shown in Table 3. The investigation of results shows that the increase of the catalyst loading causes the reduction of reaction time and the increase of reaction efficiency, too. During the dealumination of NaY zeolite by EDTA treatment, the extra-framework Al species are removed from the secondary pores which are followed by increasing the number and diameter of secondary mesoporous [24, 30]. Therefore, the catalyst loading increases and the epoxidation reaction is followed by a decrease in reaction time. The other key factor, here, is related to the size of metallocomplexes into zeolite cage. It seems that by decreasing complex size, the access to active site is likely easy, thus, the epoxidation of metallocomplexes is more rapid. Consequently, the time of reaction will be shorter and the efficiency of the reaction enhances. In addition, Table 4 compares the efficiency of our catalyst with the efficiency of some other catalysts in the epoxidation reaction of cyclooctene. It is clear that the high efficiency with the short time is obtained for our system in comparison with other heterogeneous system.

Two main routes have been known for the mechanism of alkene epoxidation via metal-catalyzed oxygen transfer including either peroxometal or oxometal species as the active intermediate. The metaloxo-catalyzed route is favorable for many first row transition metals [20]. Meanwhile, for MnTPP-MDAZY, the probable mechanism is shown in Scheme 3. In this Scheme, it seems that the epoxidation of alkenes is performed from metaloxo-catalyzed pathway.

\section{Conclusion}

In summary, in this paper, MnTPP was synthesized inside modified dealuminated $\mathrm{Y}$ zeolite by template

Table 3 Epoxidation of alkenes with $\mathrm{NaIO}_{4}$ catalyzed by Mn(TMPyP)-NaX, Mn(TMPyP)-NaY and MnTPP-MDAZY under mechanical stirring

\begin{tabular}{|c|c|c|c|c|c|c|c|c|c|c|}
\hline \multirow[t]{3}{*}{ Entry } & \multirow[t]{3}{*}{ Alkene } & \multicolumn{3}{|c|}{ Mn(TMPyP)-NaX } & \multicolumn{3}{|c|}{ Mn(TMPyP)-NaY } & \multicolumn{3}{|c|}{ MnTPP-MDAZY } \\
\hline & & \multicolumn{3}{|c|}{$0.0069 \mathrm{mmol} / \mathrm{g}^{\mathrm{a}}$} & \multicolumn{3}{|c|}{$0.0135 \mathrm{mmol} / \mathrm{g}^{\mathrm{a}}$} & \multicolumn{3}{|c|}{$0.263 \mathrm{mmol} / \mathrm{g}^{\mathrm{a}}$} \\
\hline & & $\begin{array}{l}\text { Conversion } \\
(\%)^{\mathrm{b}}\end{array}$ & $\begin{array}{l}\text { Epoxide } \\
\text { selectivity (\%) }\end{array}$ & $\begin{array}{l}\text { Time } \\
\text { (h) }\end{array}$ & $\begin{array}{l}\text { Conversion } \\
(\%)^{\mathrm{b}}\end{array}$ & $\begin{array}{l}\text { Epoxide } \\
\text { selectivity (\%) }\end{array}$ & $\begin{array}{l}\text { Time } \\
\text { (h) }\end{array}$ & $\begin{array}{l}\text { Conversion } \\
(\%)^{\mathrm{b}}\end{array}$ & $\begin{array}{l}\text { Epoxide } \\
\text { selectivity (\%) }\end{array}$ & $\begin{array}{l}\text { Time } \\
\text { (h) }\end{array}$ \\
\hline 1 & Cyclooctene & 95 & 100 & 5.5 & 97 & 100 & 5 & 100 & 100 & 3.5 \\
\hline 2 & Cyclohexene & 97 & 76 & 8 & 100 & 53 & 6.5 & 100 & 75 & 6 \\
\hline 3 & Styrene & 83 & 79 & 11 & 100 & 70 & 10 & 95 & 85 & 4 \\
\hline 4 & $\begin{array}{c}\alpha \text {-Methyl } \\
\text { styrene }\end{array}$ & 97 & 100 & 10 & 100 & 100 & 8 & 100 & 98 & 5.5 \\
\hline 5 & 1-Hexene & 89 & 100 & 18 & 97 & 100 & 12 & 95 & 100 & 8 \\
\hline 6 & 1-Decene & 50 & 100 & 18 & 52 & 100 & 16 & 70 & 100 & 10 \\
\hline
\end{tabular}

Reaction conditions: alkene $(0.5 \mathrm{mmol}), \mathrm{NaIO}_{4}(1 \mathrm{mmol})$, catalyst (600 mg for Mn(TMPyP)-NaX, Mn(TMPyP)-NaY and $200 \mathrm{mg}$ for MnTPPMDAZY, $\mathrm{CH}_{3} \mathrm{CN} / \mathrm{H}_{2} \mathrm{O}(5 / 2.5 \mathrm{ml})$

${ }^{a}$ Catalyst loading

${ }^{\mathrm{b}}$ GC yield 
Table 4 Comparison of efficiency of various catalysts in the epoxidation of cyclooctene

\begin{tabular}{|c|c|c|c|c|c|}
\hline Entry & Catalyst & Conditions & Yield $(\%)$ & Time (h) & References \\
\hline 1 & Zeolite-encapsulated ruthenium(III) salophen (ZERS) & $\mathrm{NaIO}_{4}, \mathrm{CH}_{3} \mathrm{CN} / \mathrm{H}_{2} \mathrm{O}$, r.t & 100 & 5 & {$[31]$} \\
\hline \multirow[t]{4}{*}{2} & $\mathrm{Mn}(\mathrm{PFTDCPP})$ & \multirow[t]{4}{*}{$\mathrm{PhIO}, \mathrm{CH}_{2} \mathrm{Cl}_{2}$, r.t. } & 93 & \multirow[t]{4}{*}{-} & \multirow[t]{4}{*}[32]{} \\
\hline & $\mathrm{Si}-\mathrm{Mn}(\mathrm{PFTDCPP})$ & & 95 & & \\
\hline & $\mathrm{Mn}(\mathrm{PFTDCCl} \mathrm{PP})$ & & 87 & & \\
\hline & $\mathrm{Si}-\mathrm{Mn}(\mathrm{PFTDCCl} 8 \mathrm{PP}$ & & 67 & & \\
\hline 3 & {$[\mathrm{Fe}\{\mathrm{TFPP}\}]^{+}$} & PhIO, DCE, r.t. & 98 & - & {$[33]$} \\
\hline 4 & {$[\mathrm{Fe}\{\mathrm{TFPP}\}]^{+}$} & $\mathrm{H}_{2} \mathrm{O}_{2}$, DCM:CAN, r.t. & 65 & - & [33] \\
\hline 5 & $\operatorname{Im}-[\mathrm{Fe}\{\mathrm{TFPP}\}] \mathrm{ES}$ & PhIO, DCE, r.t. & 87 & - & {$[33]$} \\
\hline 6 & $\operatorname{Im}-[\mathrm{Fe}\{\mathrm{TFPP}\}] \mathrm{ES}$ & $\mathrm{H}_{2} \mathrm{O}_{2}$, DCM:CAN: r.t. & 48 & - & {$[33]$} \\
\hline 7 & $\mathrm{Mn}(\mathrm{TDCPP}) \mathrm{Cl}$-silica & $\mathrm{H}_{2} \mathrm{O}_{2}, \mathrm{NH}_{4} \mathrm{AcO}$ (co catal) $\mathrm{ACN}$, r.t. & 72 & 19 & {$[34]$} \\
\hline 8 & {$[\mathrm{Mn}\{\mathrm{M}(4-\mathrm{N}-\mathrm{MePy}) \mathrm{TDCPP}\}] \mathrm{Cl}_{2}$} & PhIO, DCE, r.t. & 80 & 24 & {$[35]$} \\
\hline \multirow[t]{2}{*}{9} & {$[\mathrm{Mn}\{\mathrm{M}(4-\mathrm{N}-\mathrm{MePy}) \mathrm{TDCPP}\}]-\mathrm{IPG}$} & \multirow[t]{2}{*}{ PhIO, DCE, r.t. } & 92 & \multirow[t]{2}{*}{24} & \multirow[t]{2}{*}[35]{} \\
\hline & {$[\mathrm{Mn}\{\mathrm{M}(4-\mathrm{N}-\mathrm{MePy}) \mathrm{TDCPP}\}]-\mathrm{SiSO}_{3}$} & & 78 & & \\
\hline 10 & $\mathrm{Mn}($ salen)OAc & $\mathrm{NaIO}_{4}, \mathrm{CH}_{3} \mathrm{CN} / \mathrm{H}_{2} \mathrm{O}$, Imidazole, r.t. & 98 & $10 \mathrm{~min}$ & {$[36]$} \\
\hline 11 & $\mathrm{Fe}[\mathrm{T}(4-\mathrm{N}-\mathrm{MePy}) \mathrm{P}] \mathrm{Cl}_{5}$ & $\mathrm{PhIO}, \mathrm{MeOH}$, r.t. & 50 & - & {$[5]$} \\
\hline 12 & $\mathrm{Fe}[\mathrm{T}(4-\mathrm{N}-\mathrm{MePy}) \mathrm{P}] \mathrm{Cl}_{5}-\mathrm{NaX}$ & PhIO, DCE, r.t & 86 & & {$[5]$} \\
\hline 13 & $\mathrm{Fe}[\mathrm{T}(4-\mathrm{N}-\mathrm{MePy}) \mathrm{MDCPP}] \mathrm{Cl} 4$ & PhIO, CAN:DCE, r.t. & 60 & & {$[5]$} \\
\hline 14 & $\mathrm{Fe}[\mathrm{T}(4-\mathrm{N}-\mathrm{MePy}) \mathrm{MDCPP}] \mathrm{Cl} 4-\mathrm{NaX}$ & PhIO, DCE, r.t. & 95 & & {$[5]$} \\
\hline \multirow[t]{3}{*}{15} & $\mathrm{FeP}\left(\mathrm{PF}_{6}\right)_{4}$ solution & \multirow[t]{3}{*}{ PhIO, DCE: CAN, r.t. } & 95 & \multirow[t]{3}{*}{6} & \multirow[t]{3}{*}[6]{} \\
\hline & $\mathrm{FePCl}_{4}$ solution & & 40 & & \\
\hline & FeP-NaY imp & & 88 & & \\
\hline 16 & This work & $\mathrm{NaIO}_{4}, \mathrm{CH}_{3} \mathrm{CN} / \mathrm{H}_{2} \mathrm{O}$, Imidazole r.t & 95 & 3.5 & - \\
\hline
\end{tabular}

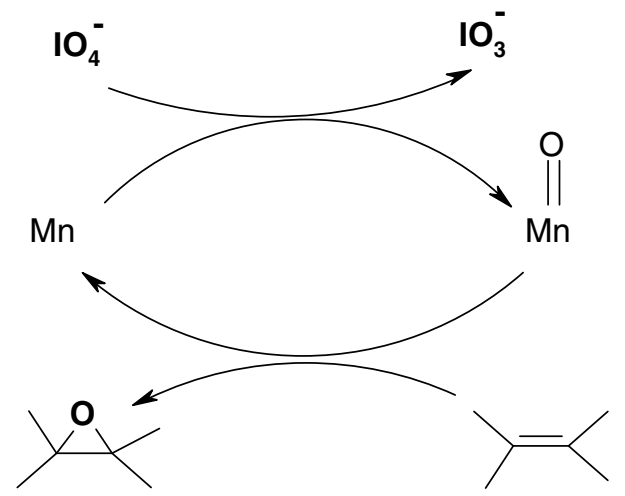

Scheme 3 Proposed mechanism for oxidation of alkenes

synthesis method. The amount of catalyst in the cage of zeolite was $0.263 \mathrm{mmol} / \mathrm{g}$ support. In comparison with other methods, high catalyst loading in this method is probably related to the small size of metalloporphyrin and the increase of mesoporous structure diameter because of removing extra-framework aluminum species from zeolite cage. Finally, the activity of catalyst was studied in the epoxidation of alkenes. The results of this study show that in this case, the time of reaction becomes shorter and the yield of reaction enhances.

Open Access This article is distributed under the terms of the Creative Commons Attribution License which permits any use, distribution, and reproduction in any medium, provided the original author(s) and the source are credited.

\section{References}

1. M.R. Maurya, A.K. Chandrakar, S. Chand, J. Mol. Catal. A Chem. 270, 225-235 (2007)

2. K.D. Karlin, Science 261, 701-708 (1993)

3. F. Bedioui, Coord. Chem. Rev. 144, 39-68 (1995)

4. I. Stiefel, in Bioinorganic Catalysis, ed. by J. Reedijk, E. Bouwman (Marcel Dekker, New York, 1999), (Chapter 3)

5. I.L.V. Rosa, C.M.C.P. Manso, O.A. Serra, Y. Iamamoto, J. Mol. Catal. A Chem. 160, 199-208 (2000)

6. F.C. Skrobot, I.L.V. Rosa, A.P.A. Marques, P.R. Martins, J. Rocha, A.A. Valente, Y. Iamamoto, J. Mol. Catal. A Chem. 237, 86-92 (2005)

7. Z. Li, C.G. Xia, X.M. Zhang, J. Mol. Catal. A Chem. 185, 47-56 (2002)

8. D.R. Leanord, J.R. Lindsay, Smith. J. Chem. Soc. Perkin Trans. 2, 1917-1923 (1990) 
9. R. Naik, P. Joshi, S. Umbarkar, R.K. Deshpande, Catal. Commun. 6, 125-129 (2005)

10. F. Algarra, M.A. Esteves, V. Fornes, H. Garcia, J. Primo, New J. Chem 333-338 (1998)

11. J. Haber, K. Pamin, J. Połtowicz, J. Mol. Catal. A Chem. 224, 153-159 (2004)

12. R.F. Parton, G.J. Peere, P.E. Neys, P.A. Jacobs, R. Claessens, G.V. Baron, S.P. Varkey, C. Ratnasamy, P. Ratnasamy, J. Mol. Catal. A 135, 295-306 (1998)

13. M.E. Davis, Acc. Chem. Res. 26, 111-115 (1993)

14. A.K. Rahiman, K. Rajesh, K.S. Bharathi, S. Sreedaran, V. Narayanan, Inorg. Chim. Acta 362, 1491-1500 (2009)

15. A. Fuerte, A. Corma, M. Iglesias, E. Morales, F. Sanchez, J. Mol. Catal. A Chem. 246, 109-117 (2006)

16. J. Połtowicz, K. Pamin, L. Matachowski, E.M. Serwicka, R. Mokaya, Y. Xia, Z. Olejniczak, Catal. Today 114, 287-292 (2006)

17. B. Sulikowski, J. Phys. Chem. 97, 1420-1425 (1993)

18. S.R. Mukai, T. Masuno, I. Ogina, K. Hashimoto, Appl. Catal. A Gen. 165, 219-226 (1997). The English Language of manuscript was essentially improved

19. B.Z. Zhan, X.Y. Li, Chem. Commun. 349-350 (1998)

20. M. Moghadam, S. Tangestaninejad, V. Mirkhani, I. Mohammadpoor-Baltork, M. Moosavifar, J. Mol. Catal. A Chem. 302, 68-75 (2009)

21. B. Sulikowski, J. Phys. Chem. 97, 1420-1425 (1993)

22. S. Nakagaki, C.R. Xavier, A.J. Wosniak, A.S. Mangrich, F. Wypych, M.P. Cantão, I. Denicoló, L.T. Kubot, Colloids Surf. A Physicochem. 168, 261-276 (2000)

23. M. Moosavifar. Submitted
24. J. Wang, Z. Wang, Z. Lin, S.Y. Han, M. Eum, C.W. Lee, J. Ind. Eng. Chem. 9, 281-286 (2003)

25. E.M. Serwicka, J. Połtowicz, K. Bahranowski, Z. Olejniczak, W. Jones, Appl. Catal. A Gen. 275, 9-14 (2004)

26. L. Barloy, J.P. Lallier, P. Battioni, D. Mansuy, Y. Piffard, M Tournoux, J.B. Valim, W. Jones, New J. Chem. 16, 71-75 (1992)

27. M.R. Maurya, A.K. Chandrakar, S. Chand, J. Mol. Catal. A Chem. 263, 227-237 (2007)

28. S. Nakagaki, C.R. Xavier, A.J. Wosniak, A.S. Mangrich, F. Wypych, M.P. Cantao, I. Denicolo, L.T. Kubota, Colloid Surf. A Physicochem. Eng. Aspect 168, 261-276 (2000)

29. M.L. Occelli, H.E. Robson, Zeolite Synthesis, American Chemical Society, Washington, DC

30. J. Wang, D. Jiang, J.O. Baeg, C.W. Lee, J. Ind. Eng. Chem. 10, 454-459 (2004)

31. B. Bahramian, V. Mirkhani, S. Tangestaninejad, M. Moghadam, J. Mol. Catal. A Chem. 244, 139-145 (2006)

32. S.L.H. Rebelo, A.R. Goncalves, M.M. Pereira, M.M.Q. Siões, M.G.P.M.S. Neves, J.A.S. Cavaleiro, J. Mol. Catal. A Chem. 256, 321-323 (2006)

33. M. Piroozmand, N. Safari, A.A. Samadi, Iran. J. Chem. Chem. Eng. 25(4), 85-89 (2006)

34. M. Moosavifar, S. Tangestaninejad, M. Moghadam, V. Mirkhani, I. Mohammadpoor-Baltork, J. Mol. Catal. A Chem. 377, 92-101 (2013)

35. F.S. Vinhado, C.M.C. Prado-Manso, H.S. Sacco, Y. Imamoto, J. Mol. Catal. A Chem. 174, 279-288 (2001)

35. B. Bahramian, V. Mirkhani, S. Tangestaninejad, M. Moghadam, J. Mol. Catal. A Chem. 244, 139-145 (2006) 